\title{
Management of grain production in modern conditions
}

\author{
Irina Avdonina*, Julia Kholopova, Tatyana Dozorova, and Elena Tarasova \\ Economics, Organization and Management at Enterprises department, Ulyanovsk State Agrarian University named after P.A. Stolypin, \\ 432017 Ulyanovsk, Russia
}

\begin{abstract}
The paper outlines the role of grain-producing companies in the agrarian sector of Ulyanovsk Oblast. It determines basic competitiveness factors of grain-producing companies in the region. An agricultural enterprise devoted to crop production of the region was assessed to provide an overview of its internal and external environment in modern conditions. The SWOT and PEST analysis tools were used therewith. The overview evaluated the efficiency of grain production at the enterprise, determined a breakeven point and margin of financial stability. This allowed the enterprise to be classified as financially unstable with a moderate bankruptcy risk. The paper also discusses the role of innovations (through the introduction of new promising and region-bound grain varieties and the use of highly-efficient liquid fertilizers) and their contribution to the development of grain production and increase in financial stability of the enterprise.
\end{abstract}

\section{Introduction}

Ulyanovsk Oblast is one of the important agrarian regions in Russia. It primarily specializes in crop production. Grain production is one of the priority sectors of crop production and the entire agrarian sector. Almost all agricultural companies of the region are involved in grain production.

The competitive capacity of grain-producing companies in Ulyanovsk Oblast is largely determined by the following: 1) fluctuations on the national grain market; 2) dynamics of regional demand for grains, which is constrained by slow animal husbandry and shrinking household demand due to higher incomes and changed food preferences; 3) price fluctuations in the energy market as expenses for fuels and lubricants account for a significant share in the cost of grain; 4) integration and concentration of capital as the profitability of vertically integrated grain producing companies is 15-20\% higher than the industry average; 5) the state of regional market infrastructure (facilities for refinement, storage, transportation of grain, marketing, lending, management and marketing consulting); 6) development of risk leveling system for business entities to provide fully insurance and risk hedging; 7) participation of local, regional and federal authorities regulating production volumes, directions of grain flows, prices, export and import of grain in the regional market.

\section{Materials and methods}

A. Alabushev, A. Altukhov, V. Butkovsky, A. Vasyutin, A. Gordeev, I. Koshkarev, V. Nechaev, O. Charykova, R. Shepitko and others addressed the current state and development of grain production. In their studies they highlighted the theoretical and methodological basis of the problem under consideration. However, many topical issues concerning management of grain production in modern conditions remain insufficiently explored, and that substantiated the goals and objectives of the study.

General scientific methods, SWOT analysis, PEST analysis, and methods of marginal analysis were used in the study.

The object of the study was OOO Irek, Melekessky District, Ulyanovsk Oblast, an agricultural company specializing in grain production.

The SWOT analysis showed that the company has all necessary conditions for the effective development of the grain industry, namely a favorable geographical position, economic potential, natural and labor resources, welldeveloped business infrastructure, and competent administration (Table 1) [1].

One of the main factors stimulating the development of grain farming is the climatic potential that contributes to the efficient management of agrarian production.

Table 2 shows the results of the PEST analysis.

The degree of impact was evaluated on a scale: high, medium, low. The level of impact ranged from -5 to +5 . Weight assignment wa based on the importance of certain factors, while a comprehensive assessment of all factors is equal to 1 .

The data in Table 2 indicate that economic factors have the greatest impact on the activities of the company. They accounted for $39 \%$ of the total factor impact. Economic factors are followed by technological factors with a share of $26 \%$. Social and political factors are equally important and therefore should not be overlooked. All macroenvironmentsl factors facilitate the

\footnotetext{
* Corresponding author: iri.avdonina@yandex.ru
} 
organization's performance. Hence, it is important to timely assess their impact and changes.

Table 1. SWOT analysis of Irek performance

\begin{tabular}{|c|c|}
\hline $\begin{array}{l}\text { Favorable factors } \\
\text { (opportunities) } \\
\text { State support. } \\
\text { Participation in } \\
\text { nationwide projects. } \\
\text { Increase in market } \\
\text { opportunities. } \\
\text { Enabling transport and } \\
\text { geographical position. } \\
\text { Well-developed } \\
\text { communications } \\
\text { framework. } \\
\text { Collaboration with } \\
\text { agricultural educational } \\
\text { institutions. } \\
\text { Credit availability. } \\
\text { Subsidies or grants. } \\
\text { Strengths } \\
\text { Sufficient amount of } \\
\text { agricultural machinery. } \\
\text { Extended reproduction of } \\
\text { fixed assets. } \\
\text { Intensive industry } \\
\text { development. } \\
\text { Highly qualified } \\
\text { administration. } \\
\text { Strong competitive } \\
\text { position. } \\
\text { Proximity of markets. } \\
\text { Adequate labour } \\
\text { resources. } \\
\text { Low staff turnover. } \\
\text { Effective incentive } \\
\text { scheme. } \\
\text { High quality products. }\end{array}$ & $\begin{array}{l}\text { Unfavorable factors } \\
\text { (threats) } \\
\text { Zone of risky agriculture. } \\
\text { Dependence of production } \\
\text { on climate. } \\
\text { Unstable agrarian market. } \\
\text { Price disparity. } \\
\text { Inadequate financing to } \\
\text { agrarian society. } \\
\text { Decrease in purchase } \\
\text { prices for grain. } \\
\text { Rise in prices for fuel and } \\
\text { spare parts. } \\
\text { Limited demand. } \\
\text { Inflation rate. } \\
\text { New competitors. } \\
\text { Need to master new } \\
\text { technologies. } \\
\text { Vulnerabilities } \\
\text { Reliance on external } \\
\text { funds. } \\
\text { Machine and tractor wear. } \\
\text { Equipment procurement } \\
\text { under finance lease or on } \\
\text { credit. } \\
\text { High cost of production. } \\
\text { Decrease in grain } \\
\text { production efficiency. }\end{array}$ \\
\hline
\end{tabular}

The analysis of grain production at OOO Irek indicates that throughout the research period, grain production at the enterprise is cost-effective (Table 3).

During 2015-2017, the production cost decreased by $14.46 \%$, the total cost of 1 decitonne of grain decreased by $12.95 \%$, and the average selling price of 1 decitonne decreased by $10.4 \%$.

An outstripping reduction in total cost compared to a drop in the cost of 1 decitonne of grain led to an increased sales profit by $73.1 \%$. The profitability of grain production increased by $3.02 \%$, sales - by $2.76 \%$

Economic activity at an enterprise calls for the management to make managerial decisions. To do this, there are some management accounting tools, one of which is break-even analysis [2].

A break-even analysis is used to establish what will happen to financial results when the level of production activity at an organization changes [3].

The analysis is valuable in that it links the decision making on cost management with production growth, prices and revenue [4].
First of all, cost management is necessary to maximize profits, improve financial conditions, boost the competitiveness of products and organization's effectiveness, and reduce the risk of bankruptcy. With this in view, it is recommended to conduct a regular financial analysis in order to minimize total costs.

Table 2. PEST analysis into macro-environmental impact on Irek performance

\begin{tabular}{|c|c|c|c|}
\hline Factors & Degree & Level & $\begin{array}{c}\text { Weight } \\
\text { assignment }\end{array}$ \\
\hline Social & & & 0.19 \\
\hline $\begin{array}{l}\text { people's attitude to } \\
\text { work and living } \\
\text { standards }\end{array}$ & High & +5 & 0.055 \\
\hline level of education & High & +5 & 0.060 \\
\hline labor mobility & Medium & +2 & 0.020 \\
\hline $\begin{array}{l}\text { demographic } \\
\text { structure of society }\end{array}$ & Medium & +3 & 0.025 \\
\hline $\begin{array}{l}\text { customs and } \\
\text { traditions }\end{array}$ & Low & -4 & 0.015 \\
\hline $\begin{array}{l}\text { shared societal } \\
\text { values }\end{array}$ & Low & -4 & 0.015 \\
\hline Technological & & & 0.26 \\
\hline $\begin{array}{l}\text { opportunities for } \\
\text { product } \\
\text { improvement }\end{array}$ & High & +5 & 0.08 \\
\hline $\begin{array}{l}\text { opportunities for new } \\
\text { products }\end{array}$ & High & +5 & 0.09 \\
\hline $\begin{array}{l}\text { modernization of } \\
\text { technology and } \\
\text { marketing of } \\
\text { manufactured } \\
\text { products }\end{array}$ & High & +5 & 0.09 \\
\hline Economical & & & 0.39 \\
\hline inflation rate & High & +5 & 0.047 \\
\hline GDP rate & Medium & +2 & 0.025 \\
\hline refinance rate & High & +5 & 0.040 \\
\hline unemployment rate & Medium & -5 & 0.023 \\
\hline $\begin{array}{l}\text { workforce } \\
\text { productivity }\end{array}$ & High & +5 & 0.045 \\
\hline salary level & High & +5 & 0.039 \\
\hline credit availability & High & +5 & 0.044 \\
\hline $\begin{array}{l}\text { degree of } \\
\text { competition }\end{array}$ & High & +5 & 0.038 \\
\hline tax system & High & +5 & 0.044 \\
\hline Political & High & & 0.16 \\
\hline legislative change & High & +5 & 0.034 \\
\hline $\begin{array}{l}\text { domestic and foreign } \\
\text { policies of the state }\end{array}$ & High & +5 & 0.036 \\
\hline legal protection & High & +5 & 0.035 \\
\hline $\begin{array}{l}\text { public control over } \\
\text { the activities of the } \\
\text { legal system }\end{array}$ & High & +5 & 0.030 \\
\hline $\begin{array}{c}\text { dynamic character of } \\
\text { the legal system }\end{array}$ & Medium & +2 & 0.025 \\
\hline Total & $\mathrm{X}$ & $\mathrm{X}$ & 1.000 \\
\hline
\end{tabular}

The break-even point is computed in terms of total revenue and total costs. For this calculation, it is important to distinguish variable and fixed costs. It should be born in mind that variable costs vary depending on the volume of outputs (raw materials, materials, components, job wages, technological energy, etc.). In turn, fixed costs do not depend on the volume of production output (in particular, these are the costs of 
repair and maintenance of equipment and buildings, rental and leasing payments, heating and lighting costs, time wages, etc.) [5].

Table 3. Economic efficiency of grain production at OOO Irek

\begin{tabular}{|l|c|c|c|c|}
\hline \multicolumn{1}{|c|}{ Indicators } & 2015 & 2016 & 2017 & $\begin{array}{c}\text { Deviation } \\
(+,-)\end{array}$ \\
\hline Grain yield, dt/ha & 14.3 & 20.2 & 25.6 & 11.3 \\
\hline $\begin{array}{l}\text { Labor costs for the } \\
\text { production of 1 decitonne } \\
\text { of grain, man-hour/dt }\end{array}$ & 0.5 & 0.1 & 0.3 & -0.2 \\
\hline $\begin{array}{l}\text { Production cost of 1 } \\
\text { decitonne of grain, RUB }\end{array}$ & 610.35 & 500.22 & 522.11 & -88.24 \\
\hline $\begin{array}{l}\text { Total cost of 1 decitonne, } \\
\text { RUB }\end{array}$ & 583.28 & 560.38 & 507.75 & -75.53 \\
\hline $\begin{array}{l}\text { Selling price of 1 } \\
\text { decitonne, RUB }\end{array}$ & 601.13 & 583.36 & 538.64 & -62.49 \\
\hline $\begin{array}{l}\text { Profit (loss) on sales of 1 } \\
\text { decitonne, RUB }\end{array}$ & 17.85 & 22.98 & 30.89 & 13.04 \\
\hline $\begin{array}{l}\text { Profitability (loss) of } \\
\text { costs, \% }\end{array}$ & 3.06 & 4.10 & 6.08 & 3.02 \\
\hline Return on sales, \% & 2.97 & 3.94 & 5.73 & 2.76 \\
\hline
\end{tabular}

The break-even point (BEP) (in terms of Unit Sales) can be calculated as:

$$
\mathrm{BP}-\mathrm{R} * \mathrm{FC} /(\mathrm{R}-\mathrm{VC}),
$$

Where $\mathrm{R}$ is revenue generated,

VC is Variable Costs,

FC is Fixed costs,

BP is break-even point in terms of Unit Sales [6].

The stability of a business determines the margin of safety, i.e. the extent to which sales exceed the threshold of profitability, otherwise referred to as margin of safety. Margin of safety shows how much a business can reduce the sales of goods without incurring losses. The extent by which current or projected output exceed break-even output is the margin of safety. Margin of safety is the most important indicator that enables a business to know what the exact amount it has gained or lost is and whether they are over or below the break-even point [7].

A break-even point calculation for grain production at OOO Irek is presented in Table 4.

Thus, the calculated break-even point by value shows that with the prevailing ratio of fixed and variable costs, the company needs to produce and sell grain in the amount of no less than RUB 18,724 thousand. With such a volume of sales, the company will fully cover all total costs through the revenue, without any profit or loss. In fact, OOO Irek sold grain in the amount of RUB 24,409 thousand in 2017, which is RUB 5,685 thousand more than the break-even point.

The calculated percentage of safety margin shows that the company can reduce grain revenue by $23.29 \%$ before it reaches the break-even point.

In addition, using the calculated margin of safety, we can consider the likelihood of bankruptcy risk of the enterprise and its financial stability (Table 5).

The calculations indicate that the company is characterized by a moderate risk of bankruptcy. During the reporting period, the company is financially fragile.
Table 4. Break-even point of grain production at OOO Irek

\begin{tabular}{|l|c|}
\hline \multicolumn{1}{|c|}{ Indicators } & 2017 \\
\hline Fixed costs - total, RUB, in thousands & 10167 \\
\hline Variable costs - total, RUB, in thousands & 11164 \\
\hline $\begin{array}{l}\text { Variable costs per 1 decitonne of grain, } \\
\text { RUB }\end{array}$ & 249.18 \\
\hline Production output, decitonne & 44803 \\
\hline Revenue, RUB, in thousands & 24409 \\
\hline Selling price of 1 decitonne, RUB & 538.64 \\
\hline $\begin{array}{l}\text { Marginal revenue - total, RUB, in } \\
\text { thousands }\end{array}$ & 13245 \\
\hline $\begin{array}{l}\text { Marginal revenue per 1 decitonne of grain, } \\
\text { RUB }\end{array}$ & 295.63 \\
\hline Margin ratio & 0.543 \\
\hline $\begin{array}{l}\text { Break-even point: } \\
\text { - by volume, decitonne }\end{array}$ & 34391 \\
\hline - by value, RUB, in thousands & 18724 \\
\hline $\begin{array}{l}\text { Margin of safety: } \\
\text { - by value, RUB, in thousands }\end{array}$ & 5685 \\
\hline - \% & 23.29 \\
\hline
\end{tabular}

Table 5. Correspondence of safety margin to the level of bankruptcy risk and financial stability

\begin{tabular}{|c|c|}
\hline $\begin{array}{c}\text { The value of } \\
\text { safety margin }\end{array}$ & $\begin{array}{c}\text { Level of bankruptcy risk and } \\
\text { financial stability }\end{array}$ \\
\hline $0.5-0.8$ & $\begin{array}{c}\text { A company is financially sound. } \\
\text { The risk of bankruptcy is minimal. }\end{array}$ \\
\hline $0.2-0.5$ & $\begin{array}{c}\text { A company is financially fragile. } \\
\text { The risk of bankruptcy is moderate. }\end{array}$ \\
\hline$<0.2$ & $\begin{array}{c}\text { A company is in financial } \\
\text { difficulty. The risk of bankruptcy is } \\
\text { high. }\end{array}$ \\
\hline
\end{tabular}

In this regard, the need for developing measures to increase grain production, improve its quality and reduce the cost of production per unit is quite obvious.

\section{Results and discussion}

Currently, an increasing number of agricultural enterprises are aware of the significant role of innovation so as to succeed and enhance their competitiveness. In reliance on the existing opportunities, agrarians are seeking to introduce new technologies, acquire advanced equipment that aids to reduce costs and improve the quality of products [8].

In modern conditions, one of the important factors contributing to the sustainability of grain production is the implementation of innovative projects, in particular, the introduction of new promising and released varieties of highly productive cereals. According to empirical studies, new varieties and high-quality seeds can encourage extra grain yields in the amount of 15-20\%. Different cultivars vary in yield and grain quality, which determines their effectiveness for production. However, these natural indicators reflect only one side of the efficiency achieved.

In a market economy, when cultivar changes is the only factor for many producers to optimize grain 
production, there is a need for an economic assessment of each variety cultivated, with respect to its quantitative and qualitative indicators [9].

In this regard, OOO Irek is proposed to grow Volzhskaya 100 winter wheat varieties. A study of the production potential showed that Volzhskaya 100 has high yield capacity. In 2008 the maximum grain yield was harvested at the Shchigrovsky variety section of the Kursk region - 95.4 dt/ha. In 2013, Volzhskaya 100 was studied under the State test system in 24 experiments and showed a yield of $42.6 \mathrm{dt} / \mathrm{ha}$.

It is proposed to grow this variety on an area of 400 hectares. Given that the seeding rate is $2.2 \mathrm{dt} / \mathrm{ha}$, the need for seeds will be $880 \mathrm{dt}$.

In addition, it is advisable to use a fertilizer KAS-32 in autumn - for the primary cultivation to produce winter grain. It is possible to order KAS-32 with a door-to-door delivery from OAO KuibyshevAzot, the manufacturer of mineral fertilizers.

The results of the activities are presented in Table 6 .

Table 6. Break-even forecast of grain production at OOO Irek

\begin{tabular}{|l|c|c|c|}
\hline \multicolumn{1}{|c|}{ Indicators } & $\begin{array}{c}\text { Actual } \\
2017\end{array}$ & $\begin{array}{c}\text { Plan } \\
2020\end{array}$ & Deviation, \pm \\
\hline $\begin{array}{l}\text { Fixed costs, total, RUB, } \\
\text { in thousands }\end{array}$ & 10167 & 10167 & - \\
\hline $\begin{array}{l}\text { Variable costs - total, } \\
\text { RUB, in thousands }\end{array}$ & 11164 & 11981 & +817 \\
\hline $\begin{array}{l}\text { Variable costs per 1 } \\
\text { decitonne of grain, } \\
\text { RUB }\end{array}$ & 249.18 & 253.71 & +4.53 \\
\hline $\begin{array}{l}\text { Production output, } \\
\text { decitonne }\end{array}$ & 44803 & 47223 & +2420 \\
\hline $\begin{array}{l}\text { Revenue, RUB, in } \\
\text { thousands }\end{array}$ & 24409 & 26493 & +2084 \\
\hline $\begin{array}{l}\text { Marginal revenue - } \\
\text { total, RUB, in } \\
\text { thousands }\end{array}$ & 13245 & 14512 & +1267 \\
\hline $\begin{array}{l}\text { Marginal revenue per 1 } \\
\text { decitonne of grain, } \\
\text { RUB }\end{array}$ & 295.63 & 307.31 & +11.68 \\
\hline Margin ratio & 0.543 & 0.548 & +0.005 \\
\hline $\begin{array}{l}\text { Break-even point: } \\
\text { - by volume, decitonne }\end{array}$ & 34391 & 33084 & -1307 \\
\hline $\begin{array}{l}\text { - by value, RUB, in } \\
\text { thousands }\end{array}$ & 18724 & 18553 & -171 \\
\hline $\begin{array}{l}\text { Margin of safety: } \\
\text { - by value, RUB, in } \\
\text { thousands }\end{array}$ & 5685 & 7940 & +2255 \\
\hline - \% & 23.29 & 29.97 & +6.68 \\
\hline
\end{tabular}

\section{Conclusion}

The implementation of the proposed measures resulted in a breakeven point reduction in volume terms by 1307 decitonne. This means that OOO Irek will need to produce and sell less grain to fully cover the costs. Margin of safety will absolutely increase by RUB 2,255 thousand or $6.68 \%$.

Thus, the "costs - volume - profit" analysis is an analysis of the behavior of costs, which is based on the relationship of costs, revenue (income), output and profit. It is a tool for management planning and control. These relationships form the basic model of financial activity, which can be used for short-term planning and evaluation of alternative solutions [10].

\section{References}

1. I.A. Avdonina, Using the direct-costing system in agricultural production management $\mathrm{J}$. of Econ. and Entrepreneurship 8-3(85), 757-760 (2017)

2. A.A. Kharchenko, Calculation of breakeven point of crop production in Coll. of papers: Proc. of the mater. of the $8^{\text {th }}$ Int. Sci. Conf. "Scientific dialogue: a young scientist" (Int. Research Federation "Social Science") 33-36 (2017)

3. A.N. Mikolyuk, M.A. Stolyarova, Break-even analysis of winter wheat production in Coll. of papers: Proc. of the 3rd Int. Sci. and Pract. Conf. "Study of the innovative potential of society and the formation of directions for its strategic development" 196-198 (Southwestern State University, 2013)

4. N.V. Speshilova, A.V. Chernova, Cost management in agricultural organizations based on the "direct costing" system in Coll. of papers: Proc. of the $5^{\text {th }}$ Int. Sci. and Pract. Conf. "Formation and implementation of strategy for sustainable economic development of the Russian Federation" 102-106 (2015)

5. L.N. Kravchenko, A.A. Morozova, Break-even point as a criterion for the success of an organization Belgorod Econ. Bull. 1(89), 237-242 (2018)

6. M.O. Kopeikin, V.V. Aleschenko, O.A. Aleschenko, Analytical support of agricultural enterprise management systems in Coll. of papers: Twentyfourth April econ. readings Proc. of Int. Sci.-Pract. Conf. 250-255 (2018)

7. G.M. Bychkova, V.A. Petronchak, D.D. Arsentieva, Analysis and calculation of the breakeven point Coll. of sci. papers of the Angarsk State Techn. Univer. 1(1), 413-421 (2016)

8. K.N. Gorpinchenko, The system of indicators of innovative development in grain production Agricult. Bull. of Stavropol Region 2(10), 152-156 (2013)

9. A.S. Lamonova, O.Yu. Antsiferova, Efficiency of innovative grain production in Proc. of the Int. Youth Agrarian Forum "Agricultural science in the innovative development of agrarian complex", Coll. of sci. articles 156-160 (2018)

10. Yu.S. Kholopova, A.A. Kazhanova, Using the "cost-volume-profit" model to determine the critical volume of grain production at the agro-industrial complex in Coll. of papers: Proc. of the National Sci. and Pract. Conf. "Science in modern conditions: from idea to implementation" 92-97 (2018) 